\title{
Modelowanie kabli w analizie zwarć i przepięć pochodzenia atmosferycznego $w$ sieciach trakcyjnych i urządzeniach sterowania ruchem kolejowym
}

\begin{abstract}
$W$ artykule omówiono elementy skladowe modelu matematycznego opisujacego przyjęty do analizy układ sieci trakcyjnej z położonym równolegle do szyn kablem. W tym celu opracowano modele elementów uktadu: sieć trakcyjna, sieć szynowa, kabel, stup, izolator, odgromnik. Wymienione elementy analizowanego uktadu zgrupowano w postaci czwórników typu П tworzqc modele czwórników reprezentujace odcinek sieci trakcyjnej. Analize prowadzono w programie LTSPICE.
\end{abstract}

\section{Wprowadzenie}

Specyficzne warunki pracy, sieci kablowej urządzeń sterowania ruchem kolejowym (srk) powodują, że jest ona narażona na wpływ różnych czynników zewnętrznych. Mogą one być przyczyną zakłóceń $w$ pracy tych urządzeń $[1,2,3]$. Ma to szczególne znaczenie dla linii zasilanych trakcją elektryczną ze względu na niebezpieczeństwo porażenia elektrycznego przy obsłudze, jak również w przypadku uszkodzenia izolacji, galwanicznego oddziaływania linii i urządzeń trakcji elektrycznej $[4,5]$.

Złożoność problematyki związanej ze zwarciami i przepięciami pochodzenia atmosferycznego $\mathrm{w}$ urządzeniach srk jest uwarunkowana wieloma czynnikami:

- znaczną rozległością obszarową,

- wzajemnym oddziaływaniem obwodów i urządzeń wysoko i niskonapięciowych przy różnych systemach zasilania

-wspólnym prowadzeniem kabli zasilających, sygnałowych, sterujących i telekomunikacyjnych

-złożonością i wzajemnym powiązaniem podsystemów, w tym urządzeń różnych generacji

-możliwością jednoczesnego oddziaływania zaburzeń z wielu źródeł.

\section{Modelowanie układu}

W opracowaniu układu do analizy założono, że ma on umożliwić analizę zwarć i przepięć pochodzenia atmosferycznego. W tym celu opracowano modele elementów układu: sieć trakcyjna, sieć szynowa, kabel, słup, izolator, odgromnik. Podzielenie układu na odcinki o długości $72 \mathrm{~m}$ pozwala na dokładniejsze modelowanie oraz obserwowanie wyników analizy w dowolnie wybranych punktach.

\subsection{Model sieci trakcyjnej}

Analiza zagrożeń urządzeń srk powodowanych zwarciami i przepięciami pochodzenia atmosferycznego $\mathrm{w}$ sieci trakcyjnej wymaga opracowania modelu uwzględniającego parametry $R, L, C$ i ich zmienności $\mathrm{W}$ funkcji częstotliwości. W analizie uwzględniono, że jest to obwód o parametrach rozłożonych. Ogólny schemat przyjętego do obliczeń odcinka sieci zasilającej i powrotnej przedstawiono na rysunku 1 [5].

Dla pasma częstotliwości uwzględnianego w tego rodzaju analizach, rzędu kilku kHz, sieć trakcyjna odpowiadająca długości odcinka między podstacjami ma długość porównywalną z długością ćwierćfali. Zgodnie $\mathrm{z}$ danymi przedstawionymi $\mathrm{w}$ pracy [5], jeżeli długość zastępczego czwórnika sieci trakcyjnej nie przekracza 3\% długości fali, to błąd takiego modelu jest mniejszy niż 2,5\%. Dla przyjętej do analizy częstotliwości $10 \mathrm{kHz}$ długość czwórnika spełniającego ten warunek wynosi $900 \mathrm{~m}$. W utworzonym modelu obliczeniowym jako długość modelowanego odcinka przyjęto odległość między dwoma słupami sieci trakcyjnej tj. $72 \mathrm{~m}$.

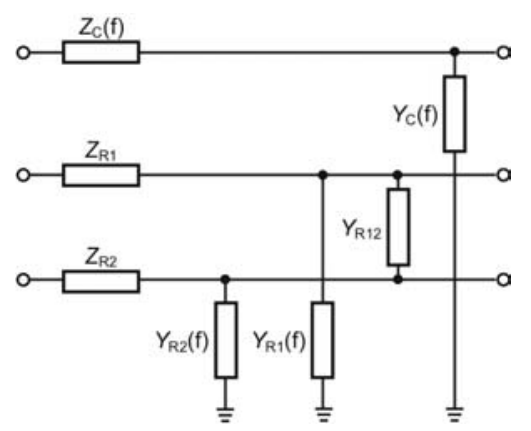

Rys. 1. Model impedancyjno - admitancyjny odcinka toru [5] 
Wyznaczone dla odcinka sieci trakcyjnej (rys. 2) o długości $72 \mathrm{~m}$, parametry z pomiarów [5], przy uwzględnieniu częstotliwościowo zależnej charakterystyki parametrów przewodów wynosiły: $R_{1}=5,04$ $\mathrm{m} \Omega, L_{1}=97,35 \mu \mathrm{H}, R_{2}=16,45 \mathrm{~m} \Omega, L_{2}=12,39 \mu \mathrm{H}, R_{3}$ $=118,34 \mathrm{~m} \Omega, L_{3}=4,19 \mu \mathrm{H}, C_{0}=2,32 \mathrm{nF}$ [5].

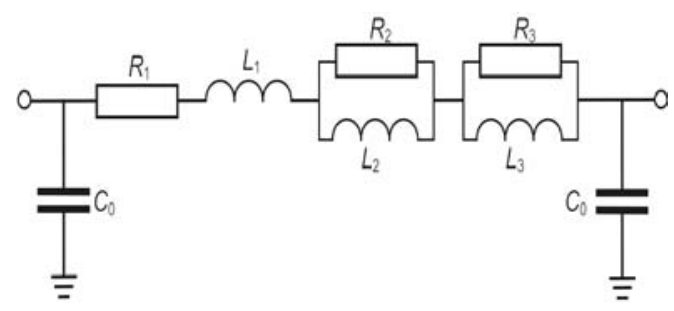

Rys. 2. Czwórnik jako element modelu sieci trakcyjnej uwzględniający zmienność parametrów w funkcji częstotliwości [5]

\subsection{Sieć szynowa i parametry elektryczne toru}

Parametry szyn wyznaczone na podstawie wyników pomiarów zamieszczonych w [5] dla długości odcinka $72 \mathrm{~m}$ wynosiły (rys. 3): $R_{1}=0,576 \Omega, L_{1}=$ $0,0576 \mathrm{mH}, \mathrm{G}_{12}=0,115 \mathrm{~S}, C_{12}=1,44 \mu \mathrm{F}$. W podobny sposób wyliczono parametry zastępcze czwórnika opisującego odcinek sieci szynowej przy uwzględnieniu ich zmienności w funkcji częstotliwości (szyna 1 ): $\mathrm{G}_{1}=6,24 \mathrm{mS}, \mathrm{C}_{1}=3,98 \mu \mathrm{F}, \mathrm{G}_{2}=6,07 \mathrm{mS}, \mathrm{C}_{2}=$ $0,37 \mathrm{mF}, \mathrm{G}_{3}=13,3 \mathrm{mS}, \mathrm{C}_{3}=5,94 \mu \mathrm{F}, \mathrm{G}_{4}=0,305 \mathrm{~S}$, $\mathrm{C}_{4}=3,06 \mu \mathrm{F}[11]$.

Takie same wartości przyjęto dla drugiego czwórnika połączonego $\mathrm{z}$ szyną 2 . Uwzględniono również połączenia wyrównawcze pomiędzy szynami, co około $300 \mathrm{~m}$.

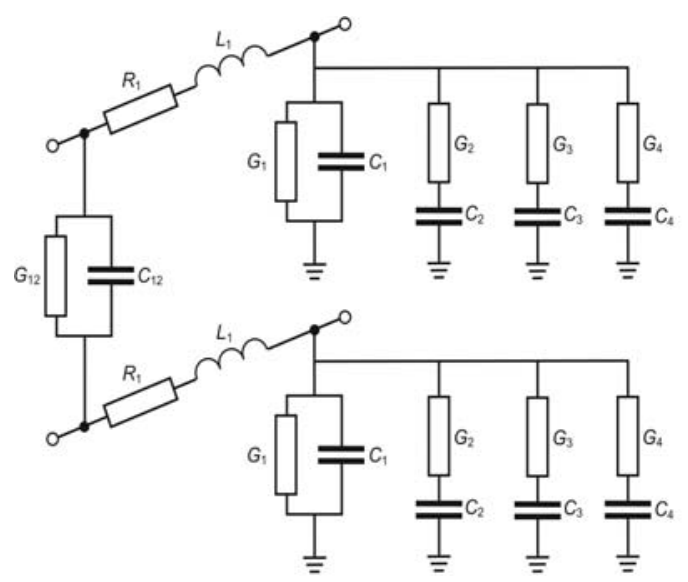

Rys. 3. Schemat odcinka toru kolejowego z uwzględnieniem wpływu ziemi [5]

\subsection{Model podstacji}

Jako model podstacji (rys. 4) przyjęto parametry uwzględniające: napięcie podstacji $U_{p}=3450 \mathrm{~V}$, indukcyjność podstacji i systemu zasilania $L_{p}=4,774$ $\mathrm{mH}$ [6]. Parametry kabla powrotnego i zasilającego wprowadzono, zgodnie $\mathrm{z}$ wynikami pomiarów zamieszczonymi w pracy [6], dla częstotliwości $10 \mathrm{kHz}$ i długości kabla 200 m jako: $R_{\mathrm{Kz}}=R_{\mathrm{Kp}}=3 \Omega, L_{\mathrm{Kz}}=$ $L_{\mathrm{Kp}}=0,13 \mathrm{mH}, \mathrm{C}_{\mathrm{Kz}}=\mathrm{C}_{\mathrm{Kp}}=0,4 \mu \mathrm{F}$. Model ten przyjęty do obliczeń jako czwórnik może być rozbudowywany w dalszych symulacjach.

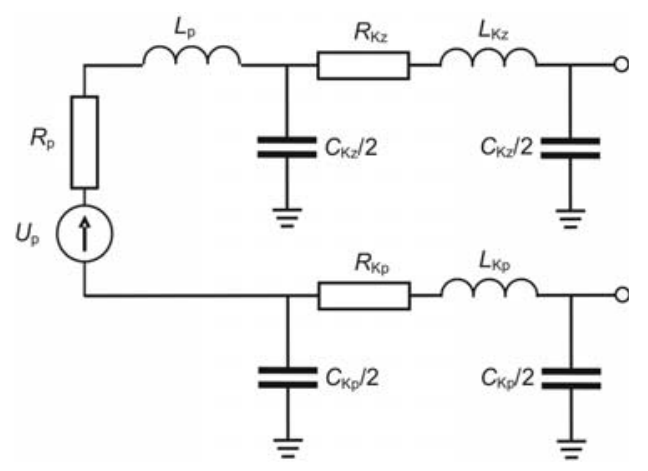

Rys. 4. Uproszczony schemat podstacji trakcyjnej i połączeń kablowych [6]

\subsection{Słupy}

W analizie zwarć i przepięć pochodzenia atmosferycznego, model słupa może być realizowany jako szeregowe połączenie indukcyjności i rezystancji. Zakładając indukcyjność jednostkową $L_{0}=1,67$ $[\mu \mathrm{H} / \mathrm{km}]$ wyznaczoną z zależności:

$$
L=0,2 \mu_{r} \frac{2 h}{r}[\mu \mathrm{H} / \mathrm{km}]
$$

gdzie: $\mu_{r}$ - przenikalność magnetyczna względna

$h$ - wysokość słupa

$r$ - promień zastępczy słupa

przyjęto indukcyjność słupa $L=20,28 \mu \mathrm{H}$, a rezystancję uziemienia słupa jako $R=10 \Omega$. Jako uszynienie słupa przyjęto indukcyjność $L=5 \mu \mathrm{H}$ [7].

\subsection{Odgromniki i iskierniki}

$\mathrm{W}$ analizie jako model izolatora uwzględniono $\mathrm{w}$ modelu słupa wyłącznik sterowany napięciem $90 \mathrm{kV}$. Model odgromnika rożkowego wprowadzono natomiast jako wyłącznik sterowany napięciem o wartości napięcia przeskoku $12 \mathrm{kV}$ i powietrznej przerwie o rezystancji $100 \mathrm{M} \Omega[7,8]$.

Odgromniki rożkowe, stosowane do ochrony sieci trakcyjnej, są instalowane co $1200 \mathrm{~m}$ lub $600 \mathrm{~m}$ (dla terenów o dużej intensywności burzowej, więcej niż $30 \mathrm{dni}$ ). W analizie uwzględniono odległości 600 $\mathrm{m}$.

\section{Model czteroprzewodowej wzajemnie sprzężonej linii długiej}

Wyznaczenie parametrów $L$ i $C$ linii długiej 37-o żyłowego kabla YKSY(żo) dla przyjętych parametrów jednostkowych i przy zastosowaniu równań analizy obwodów elektrycznych omówiono w [9]. W referacie oddziaływanie pomiędzy siecią trakcyjna, szynami i kablem do urządzeń srk uwzględniono (rys. 5) stosując model czteroprzewodowej wzajemnie 
sprzężonej linii długiej z wykorzystaniem źródeł sterowanych $\mathrm{w}$ programie LTSPICE [10]. W tego rodzaju analizie kabel wielożyłowy dla uproszczenia jest zamodelowany jako pojedynczy przewód [11].

Do analizy przyjęto parametry geometryczne, jak rysunku 5. Długość odcinków odpowiada odległości pomiędzy słupami trakcyjnymi i wynosi 72 $\mathrm{m}$. W przyjętym układzie kabel jest umieszczony na powierzchni ziemi w odległości $1,5 \mathrm{~m}$ od osi toru.

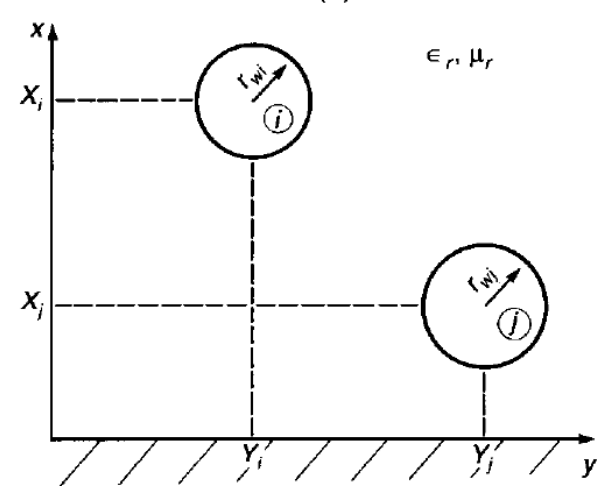

Rys. 5. Model wzajemnie sprzężonej linii długiej dla dwóch przewodów umieszczonych w ośrodku jednorodnym [10]

Symulację prowadzono dla układu składającego się z 178-u sekcji, dających model linii o długości 12,82 km. Model linii bezstratnej ze sprzężeniami uzupełniono o straty podłużne jak (w pkt 2.1 i 2.2 ) umieszczone w węzłach między sekcjami linii. Do uwzględnienia sprzężeń pomiędzy poszczególnymi przewodami wprowadzono przedstawiony na rysunku 7 model wzajemnie sprzężonej czteroprzewodowej linii długiej z wykorzystaniem źródeł sterowanych [10]

$$
\mathrm{o}^{\mathrm{Pj}}
$$

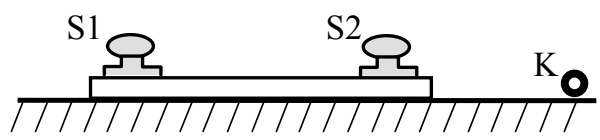

Rys.6. Widok poprzeczny sieci trakcyjnej i torów z pobliskim kablem

Do symulacji przepięć pochodzenia atmosferycznego przyjęto wymuszenie w postaci udaru prądowego $8 / 20 \mu$ s, jak na rysunku 8 . Dla celów symulacji komputerowych oraz do projektowania generatorów udarów podawane są zależności matematyczne definiujące parametry i kształty impulsów [12]. Impuls prądowy $8 / 20 \mu$ s może być przybliżony zależnością:
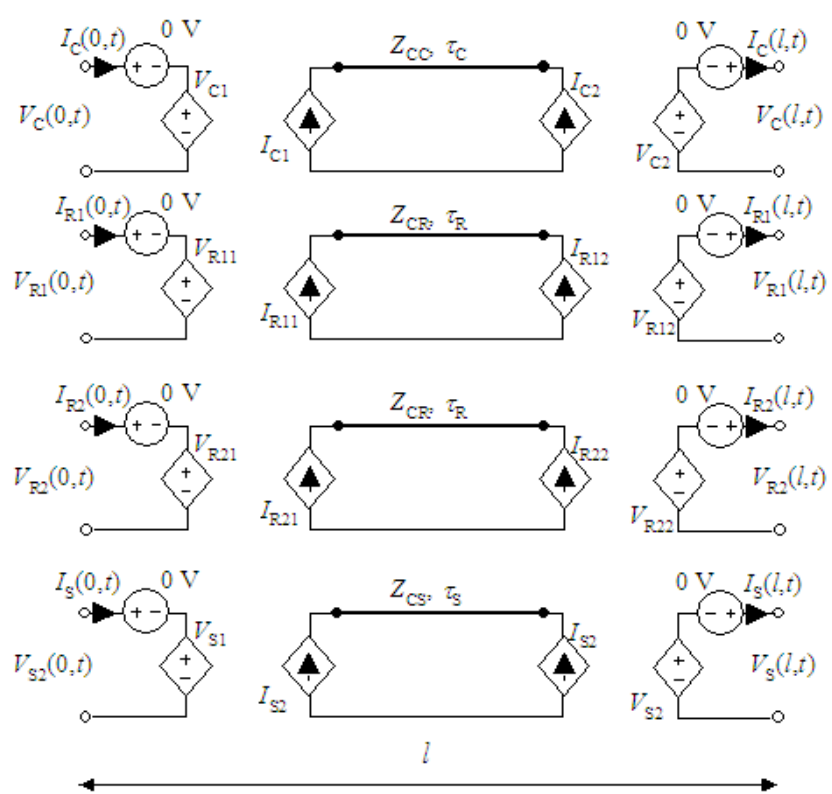

Rys. 7. Model wzajemnie sprzężonej czteroprzewodowej linii długiej z wykorzystaniem źródeł sterowanych [10]

$$
i(t)=A I_{p} t^{3} \exp (-t / \tau)
$$

z parametrami wynoszącymi: $A=0,01243(\mu \mathrm{s})^{-3}$; $\tau=3,911 \mu \mathrm{s}$.

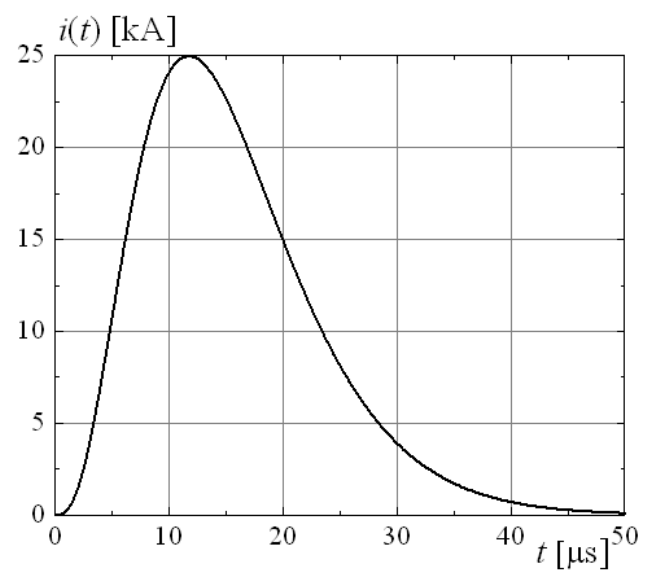

Rys. 7. Przebieg udaru prądowego $8 / 20 \mu \mathrm{s}, \mathrm{I}_{\mathrm{p}}=25 \mathrm{kA}$ [14]

Poziomy odporności na udary urządzeń srk są określone w normie PN-EN50121-4, 2002(U) [15]. Modelowanie i analiza zwarć w opracowanym układzie wymaga znacznie dłuższego (około $60 \mathrm{~ms}$ ) czasu obserwacji. Zwiększa to w znaczący sposób plik wynikowy. Realizowano ją poprzez doprowadzanie idealnego źródła zwarcia. Otrzymywane charakterystyki mogą być przybliżone zależnością [16]:

$$
i=\frac{E}{R}\left(1-e^{-\frac{t}{T}}\right)
$$

gdzie: E - napięcie źródłowe

$\mathrm{R}$ - rezystancja obwodu

$\mathrm{T}$ - stała czasowa obwodu $\frac{L}{R}$. 
Poniżej przedstawiono przykładowe przebiegi $\mathrm{z}$ modelowania propagacji sygnałów napięciowych dla wymuszenia w postaci fali prądowej $8 / 20 \mu \mathrm{s}(I$ $\max _{\max }=25 \mathrm{kA}$ ). Do analizy modele elementów przyjętego układu zgrupowano w postaci czwórników typu $\Pi$ tworząc dwa modele czwórników zawierające odcinek sieci trakcyjnej i toru o długości $72 \mathrm{~m}$ oraz:

$$
1 \text { - słup z izolatorem }
$$

2 - słup z odgromnikiem rożkowym.

Przyjęto odcinek zawierający 178 czwórników. Źródło zwarcia doprowadzono do czwórnika 93 realizując zwarcie pomiędzy szyną i kablem:

Poniżej przedstawiono wybrane przebiegi napięć dla słupa z doprowadzonym udarem (linia ciagła) i dwóch kolejnych słupów (linia przerywana i kropkowa) w miejscu ich połączenia z wyłącznikiem. Na kolejnym rysunku 9 zamieszczono przebiegi napięć dla tych samych słupów w miejscu połączenia z szyna.

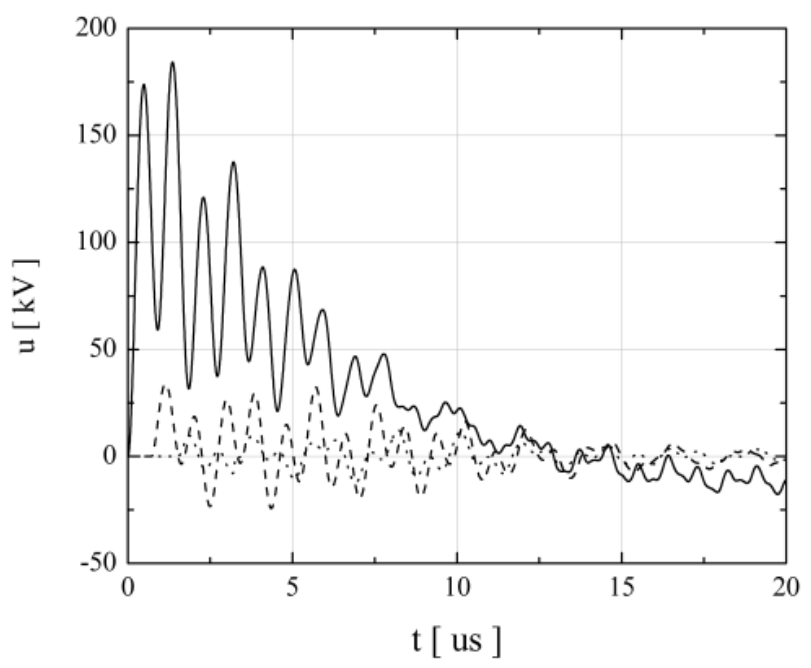

Rys. 8. Przebiegi napięć dla modelu wzajemnie sprzężonej linii długiej na słupie, do którego doprowadzono udar o kształcie 8/20 $\mu$ s i wartości maksymalnej $25 \mathrm{kA}$ (linia ciagła) oraz kolejnych słupach w odległości 72 m (linia kreskowana) i 144m (linia kropkowana)

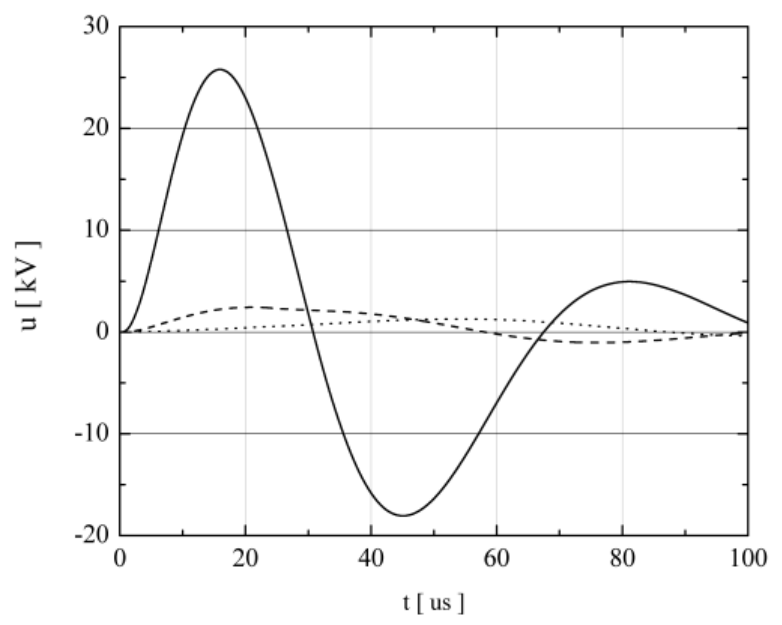

Rys. 9. Przebiegi napięć dla słupów z rys. $8 \mathrm{w}$ miejscu połączenia z szyną

\section{Podsumowanie}

W referacie omówiono elementy składowe modelu matematycznego opisującego przyjęty do analizy układ sieci trakcyjnej z położonym równolegle do szyn w odległości 1,5 m od osi toru kablem. Wprowadzono model wzajemnie sprzężonej linii długiej. Zbudowany model sieci złożony został z elementów opisanych w punkcie 2 i może reprezentować odcinek sieci trakcyjnej o dowolnej długości. Zawarte elementy składowe wprowadzone w postaci czwórników można rozbudowywać lub uzupełniać o kolejne w zależności od rodzaju stosowanych elementów rzeczywistego układu.

\section{Wnioski}

Ocena zagrożeń urządzeń srk powodowanych zwarciami i przepięciami pochodzenia atmosferycznego $\mathrm{w}$ sieciach trakcyjnych wymaga prowadzenia pomiarów i dokładnych analiz rozpływu prądów i spadków napięć w elementach konstrukcyjnych i instalacyjnych analizowanych urządzeń. Zastosowanie programu LTSPICE znacznie ułatwia skomplikowaną analizę oraz ocenę zachodzących zjawisk. Rozeznane możliwości programu mają charakter poznawczy i zostaną wykorzystane do dalszej analizy i oceny zagrożeń elementów zasilania urządzeń kolejowych.

\section{Literatura}

1. A. Kulawiak, B. Kabacińska, A Kaźmierczak-"Analiza stanu i ocena ochrony przeciwprzepięciowej urzqdzeń srk na sieci PKP. Etap 1. Przygotowanie zbioru dokumentacji najczęściej uszkadzanych urzqdzeń srk”. Wersja 2, 4036/20. CNTK, Warszawa, 2003

2. A. Kulawiak, B. Kabacińska, A. Kaźmierczak - "Analiza stanu $i$ ocena ochrony przeciwprzepięciowej urzqdzeń srk na sieci PKP. Etap 2. Analiza uszkodzeń urzqdzeń srk spowodowanych przepięciami”. Wersja 2. Nr 4036/20. CNTK, Warszawa, 2003

3. M. Laskowski, A. Kulawiak - "Ochrona przeciwprzepięciowa i przeciwporażeniowa $w$ urzadzeniach srk $z$ elementami elektronicznymi”. Praca CNTK, 1002/24, Warszawa 1994

4. M. Laskowski, R. Malesa, Z. Wróbel i inni "Określenie istniejacych poziomów zaktóceń elektromagnetycznych $w$ ruchomych $i$ stacjonarnych obiektach kolejowych”. Praca CNTK (Zakład Telekomunikacji) $n r$ 1049/24, Warszawa 1997

5. A. Szelag - "Zagadnienia analizy $i$ projektowania systemu trakcji elektrycznej prqdu statego z zastosowaniem technik modelowania i symulacji". Prace Naukowe, Elektryka z. 123, Oficyna Wydawnicza Politechniki Warszawskiej, Warszawa 2002

6. A. Białoń, A. Kaźmierczak, W. Zajac-"Opracowanie dopuszczalnych parametrów zakłóceń dla urzqdzeń srk, łaczności i pojazdów trakcyjnych”. Sprawozdanie końcowe. Praca 6915/23, CNTK, Warszawa 1999 
7. Z. Wróbel - "Computer modelling of lightning discharge threat to railway installations", MODERN ELECTRIC TRACTION. POWER SUPPLY. Edited by Krzysztof Karwowski, Adam Szelag, Gdansk Uniwersity of Technology, Faculty of Electrical and Control Engineering. Gdańsk 2009

8. Z. Wróbel, R. Ziemba - "Computer modelling of the railway electric traction cused by fast surges", MODERN ELECTRIC TRACTION. POWER SUPPLY. Edited by Krzysztof Karwowski, Adam Szelag, Gdansk Uniwersity of Technology, Faculty of Electrical and Control Engineering. Gdańsk 2009

9. Z. Wróbel - "Zastosowanie modelu kabla wielożyłowego $w$ analizie zagrożeń urzadzeń sterowania ruchem kolejowym", Politechnika Krakowska im. Tadeusza Kościuszki, Wydziat Inżynierii Elektrycznej $i$ Komputerowej; XIV Ogólnopolska Konferencja Naukowa Trakcji Elektrycznej, VI Szkoła Kompatybilności Elektromagnetycznej $w$ Transporcie, Zakopane, październik 2010, 373-382
10. Paul R. Clayton - "Introduction to Electromagnetic Compatibility". John Wiley \& Sons, Inc. Published by John Wiley \& Sons, Inc., Hoboken, New Jersey. Published simultaneously in Canada, 2006

11. A. S. Ahmad, T. Aka-Ngnui - "Lightning induced voltage on telephone cables and power systems", International Conference on Power Systems Transients (IPST'07) in Lyon, France on June 4-7, 2007

12. PN-EN 61000-4-5, (1998) -Kompatybilność elektromagnetyczna (EMC). Metody badań $i$ pomiarów. Badania odporności na udary

13. PN-EN50121-4, 2002(U) -Zastosowania kolejowe. Kompatybilność elektromagnetyczna Część 4, Emisja $i$ odporność na zakłócenia urzqdzeń sygnalizacji $i$ telekomunikacji

14. L. Mierzejewski, A. Szelag, M. Gałuszewski-"System zasilania trakcji elektrycznej pradu stałego", Wydawnictwa Politechniki Warszawskiej, Warszawa, 1989 